\title{
PENGOLAHAN DAN UJI ORGANOLEPTIK IKAN ASIN DI DESA GALO-GALO KABUPATEN PULAU MOROTAI
}

\author{
Nender Puni, Rinto Muhammad Nur, Asy’ari \\ Program Studi Teknologi Hasil Perikanan, Fakultas Perikanan dan IImu \\ Kelautan Universitas Pasifik Morotai, Maluku Utara, Indonesia \\ E-mail: rintomnur777@gmail.com
}

Received February 2020, Accepted June 2020

\begin{abstract}
ABSTRAK
Pengolahan ikan secara tradisional merupakan bentuk pengolahan yang banyak dilakukan nelayan, khususnya di Desa Galo-Galo Kecamatan Morotai Selatan. Ikan asin sangat digemari oleh masyarakat bahkan dijadikan oleh-oleh khas Morotai. Ikan asin ini biasanya dijual ke pasar tradisional Pulau Morotai dan daerah sekitarnya. Penelitian ini bertujuan untuk mengetahui proses dan uji organoleptik ikan asin di Desa GaloGalo, Kabupaten Pulau Morotai. Penelitian ini dilakukan pada bulan Juli sampai Agustus 2019 bertempat di Desa Galo-Galo, Morotai Selatan, Pulau Morotai. Pengamatan proses pembuatan ikan asin dan uji organoleptik menggunakan angket dan pengamatan langsung. Uji organoleptik ikan asin meliputi kenampakan, rasa, bau, tekstur, dan jamur. Hasil penelitian menunjukkan bahwa proses pembuatan ikan asin di Desa Galo-Galo meliputi pembuangan bagian ikan yang tidak digunakan (sisik, isi perut dan insang), dicuci, dibilas, diberi garam, direndam, dicuci kembali, dan dijemur. Hasil uji organoleptik ikan asin dari Desa Galo-Galo menunjukkan bahwa ikan layak dikonsumsi karena memiliki nilai organoleptik $>7$.
\end{abstract}

Kata Kunci : Pengolahan Ikan, Ikan Asin, Organoleptik

\section{ABSTRACT}

SALTED FISH PROCESSING AND ORGANOLEPTIC TESTING AT THE GALO-GALO VILLAGE OF PULAU MOROTAI REGENCY. Traditional fish processing is a form of processing that is mostly done by fisherman especially in the village of Galo-Galo South Morotai District. Salted fish is very popular with the community and even made a souvenir typical of Morotai. This salted fish is usually sold to the traditional markets of Pulau Morotai and the surrounding area. This study aims to determine the process and organoleptic of salted fish in the Galo-Galo village, Pulau Morotai regency. This research was conducted from July to August 2019 in Galo-Galo village Pulau Morotai. To observe the process of making salted fish, and organoleptic, the researcher used a questionnaire and direct observation. Here's the process of making salted fish: first of all, 
clean your fish well and remove from stomach contents and gills then rinse them and rub them with plenty of salt. Finally, hang the fish in the sun. Organoleptic test of salted fish from this village was very suitable for consumption because the value of organoleptic was very good (>7).

Keywords : Fish Processing, Salted Fish, Organoleptic

\section{PENDAHULUAN}

Ikan merupakan salah satu sumber protein hewani yang banyak dikonsumsi masyarakat, mudah didapat, dan harganya murah (Margono et al., 2000). Hasil perikanan merupakan komoditas yang mudah mengalami kemunduran mutu dan proses pembusukan, sehingga perlu penanganan yang cepat, tepat dan benar untuk menjaga kualitasnya. Hasil perikanan di Indonesia pada umumnya disajikan dalam dua bentuk, yaitu segar dan olahan. Penyajian ikan secara olahan meliputi olahan tradisional dan olahan moderen.

Kegiatan pengolahan ikan secara tradisional dapat dilakukan dengan cara pengeringan dan penggaraman.Cara ini merupakan bentuk pengolahan yang banyak dilakukan nelayan, khususnya di Desa GaloGalo, Kecamatan Morotai Selatan, Kabupaten Pulau Morotai.Masyarakat Desa Galo-Galo banyak yang bermata pencaharian sebagai nelayan.Usaha pembuatan ikan asin terletak di pesisir pantai dan memiliki potensi perikanan laut yang potensial untuk dikembangkan.Bahan baku yang digunakan didapat dari nelayan setempat yang juga merupakan pengolah ikan asin. Secara umum, kegiatan pengolahan ikan secara tradisional di Desa Galo-Galo mampu memberikan nilai tambah.

Ikan asin adalah salah satu jenis olahan hasil perikanan yang ada di Kabupaten Pulau Morotai. Ikan asin sangat digemari oleh masyarakat bahkan dijadikan oleh-oleh khas Morotai. Ikan asin ini biasanya dijual ke pasar tradisional Pulau Morotai dan daerah sekitarnya. Pengolahan ikan asin ini bertempat di Desa Galo-Galo, Kecamatan Morotai Selatan, Kabupaten Pulau Morotai.Selain itu, pengolahan ikan asin juga telah diproduksi oleh masyarakat desa lain seperti Desa Kolorai, Tiley Pante, Pandanga, dan Wayabula.

Pengolahan ikan di Desa Galo-Galo masih skala industri rumah tangga, selain itu proses pengolahannya masih secara tradisional. Produksi dalam skala industri rumah tangga dan secara tradisional biasanya kurang memperhatikan sanitasi dan higiene selama proses pengolahan. Sanitasi dan higiene merupakan salah satu faktor yang mempengaruhi mutu produk pangan. Selain itu, ada beberapa faktor yang mempengaruhi mutu ikan asin yaitu faktor kimia, biologi dan organoleptik. Organoleptik merupakan salah satu pengujian produk pangan dengan menggunakan organ tubuh sebagai penentu. Uji organoleptik meliputi kenampakan, aroma, tekstur, rasa dan jamur.

Penelitian ini bertujuan untuk mengetahui proses pembuatan dan nilai organoleptik ikan asin di Desa Galo-Galo, Kabupaten Pulau Morotai. 


\section{Waktu dan Tempat}

\section{MATERI DAN METODE}

Penelitian ini dilakukan pada bulan April sampai Juni 2019 bertempat di Desa Galo-Galo, Kecamatan Morotai Selatan Kabupaten Pulau Morotai.

\section{Prosedur Penelitian}

Pengambilan data melalui pengamatan langsung dan wawancara menggunakan angket. Sebelum pengambilan data, dilakukan survey awal untuk menentukan responden/narasumber. Pelaku usaha yang ditetapkan sebagai narasumber dalam penelitian ini adalah pelaku usaha yang selalu melakukan produksi.

Wawancara dilakukan dengan cara menanyakan langsung pertanyaan yang telah dibuat dalam angket penelitian kepada pelaku usaha ikan asin di Desa Galo-Galo. Wawancara dimaksudkan untuk mendapatkan informasi sekitar pembuatan ikan asin. Pengamatan dilakukan dengan cara mencermati langsung secara visual proses pembuatan ikan asin yang ada di Desa Galo-Galo. Pengamatan dimaksud agar setiap tahapan pembuatan ikan asin di Desa Galo-Galo dapat diketahui.

Uji organoleptik dilakukakan oleh panelis konsumen terhadap ikan asin. Panelis memberikan penilaian mutu ikan asin menggunakan angket yang telah disiapkan. Panelis mengamati dan memberi nilai organoleptik ikan asin meliputi rasa, aroma, tekstur, kenampakan, dan jamur.

\section{Analisis Data}

Data yang diperoleh dianalisis secara deskriptif.

\section{HASIL DAN PEMBAHASAN}

\section{Gambaran Umum Tempat usaha Ikan Asin}

Usaha pembuatan ikan asin milik Bapak Firman Syah Sanaky merupakan salah satu Usaha Kecil Menengah (UKM) yang bergerak dalam bidang pengolahan hasil perikanan. Usaha ikan asin ini masih dalam skala industri rumah tangga yang pengolahannya dilakukan oleh Bapak Firman sendiri dan dibantu oleh 3 orang karyawan yang merupakan anggota keluarga. Usaha ini berdiri sejak tahun 2008.

Bahan baku yang digunakan dalam pengolahan ikan asin adalah ikan demersal hasil tangkapan nelayan setempat. Jenis-jenis ikan yang digunakan sebagai bahan baku pengolahan ikan asin di Galo-Galo Kecamatan Morotai Selatan, Kabupaten Pulau Morotai dapat dilihat dalam Tabel 1 di bawah ini. 
Tabel 1. Jenis ikan yang dijadikan ikan asin di Desa Galo-Galo

\begin{tabular}{clll}
\hline \multirow{2}{*}{ No } & \multicolumn{2}{c}{ Jenis Ikan } \\
\cline { 2 - 4 } & Nama lokal & Nama Nasional & Nama ilmiah \\
\hline 1 & Gutila & Lencam & Lethrinus lentjan \\
2 & Gaca & Cunding & Lutjanus gibbus \\
4 & Skuda nyare & Tambak pasir & Lethrinus nebulosus \\
5 & Biji nangka & Biji nangka & Parupeneus barberinus \\
\hline
\end{tabular}

Bahan baku diperoleh dari nelayan yang berasal dari Desa GaloGalo. Selain bahan baku berupa ikan, dalam usaha ini juga dibutuhkan beberapa bahan seperti air bersih, garam dan kadang-kadang membutuhkan es. Peralatan yang digunakan selama proses pengolahan ikan berupa baskom, pisau dan cool box. Dalam sekali produksi biasanya Bapak Firman memproduksi 50-100 ekor ikan asin. Pengolahan ikan asin dilakukan setiap hari dan biasanya disesuaikan dengan hasil tangkapan nelayan.

\section{Proses Pengolahan Ikan Asin}

Proses pengolahan ikan yang dilakukan oleh pelaku usaha meliputi ikan dibuka sisik, dibelah, dibuang insang, isi perut dan mata, dicuci, diberi garam, dibiarkan selama 1 jam, dicuci kembali, dan dijemur. Adapun diagram alir pembuatan ikan asin di Desa Galo-Galo, Kecamatan Morotai Selatan, Kabupaten Pulau Morotai dapat dilihat dalam Gambar 1.

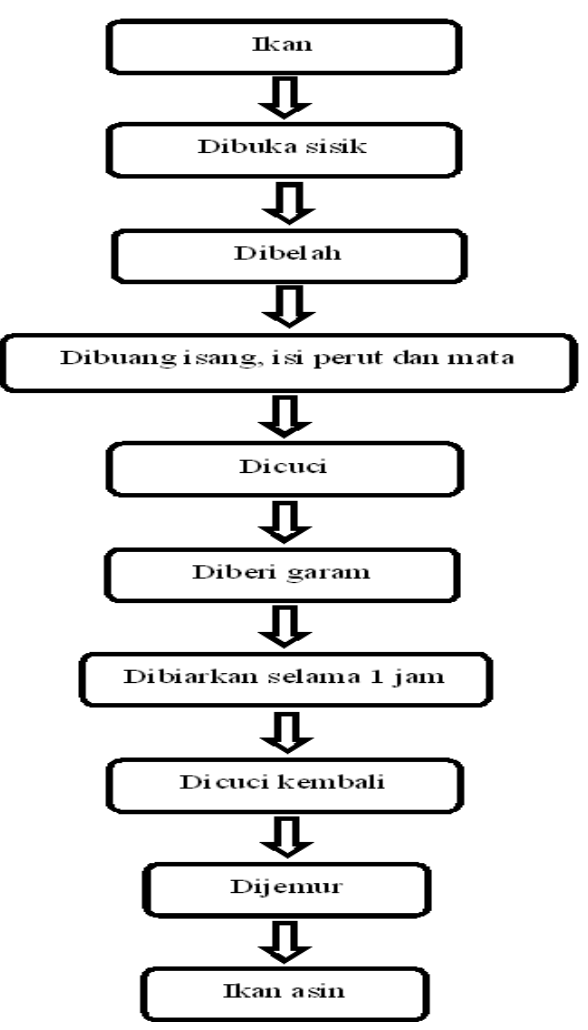

Gambar 1. Proses pembuatan ikan asin di Desa Galo-Galo. 
Tahap pertama dalam pembuatan ikan asin yaitu ikan hasil tangkapan awalnya dibuka sisik di bagian kulit ikan. Ikan yang biasa digunakan pada pembuatan ikan asin di Desa Galo-Galo adalah ikan demersal yang memiliki karakteristik bersisik di bagian kulit sehingga sisik yang ada di kulit ikan tersebut harus dibersihkan, agar ikan mudah dibelah dan pada waktu penggaraman, garam akan meresap di bagian ikan dengan merata dan pada waktu penjemuran ikan dapat kering secara merata.

Tahapan selanjutnya yaitu ikan dibelah (Gambar 2), insang dan isi perut dibuang, kemudian ikan dicuci. Ikan dicuci menggunakan air bersih. Pencucian bertujuan untuk menghilangkan sisa-sisa kotoran dan darah ikan yang masih menempel di daging ikan. Wibowo (1995) menjelaskan bahwa penyiangan dan pencucian bertujuan untuk menghilangkan kotoran, sisik dan lendir dengan membelah bagian perut sampai dekat anus, menghilangkan sisa kotoran, darah dan lapisan dinding yang berwarna.

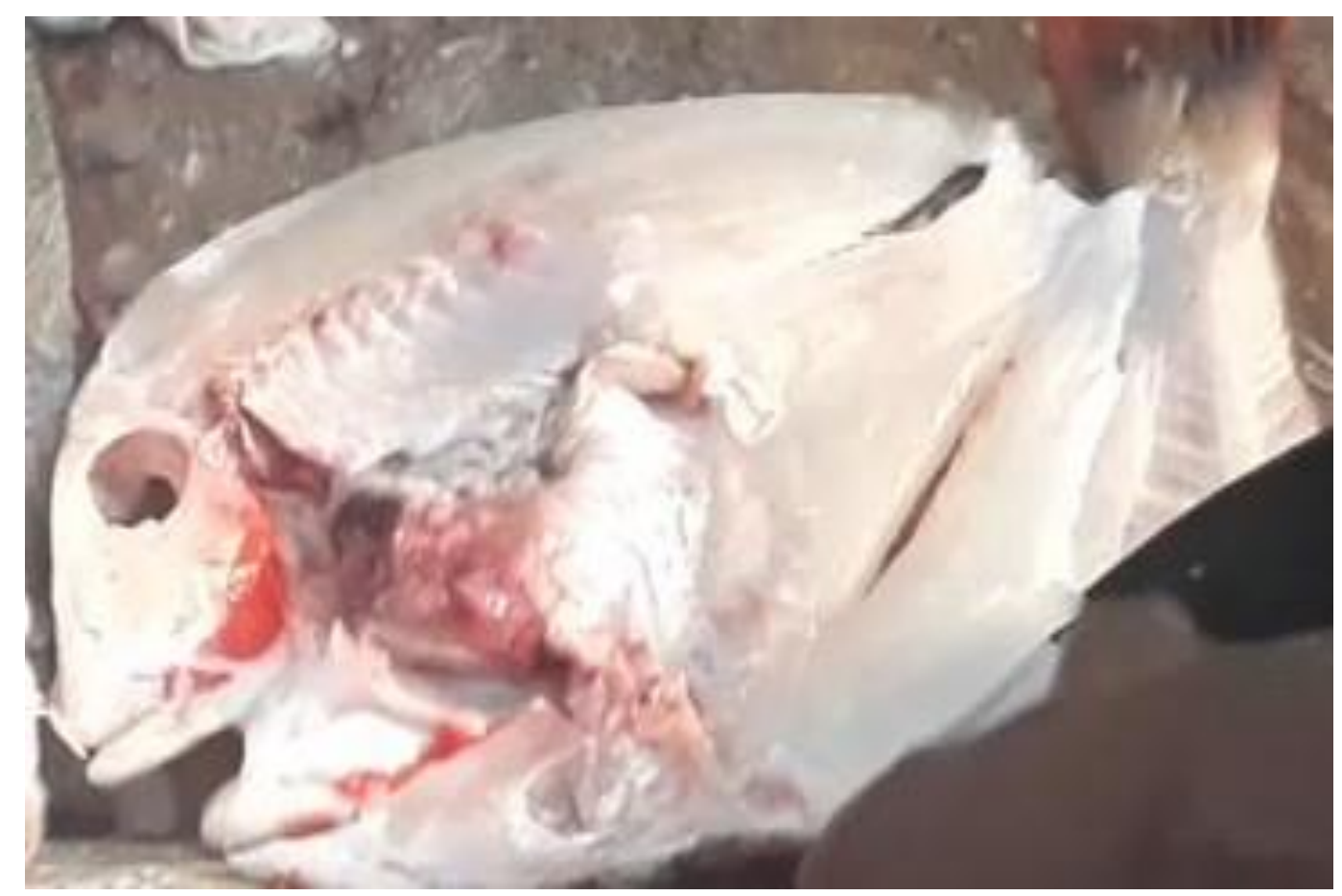

Gambar 2. Kondisi ikan setelah dibelah.

Tahap selanjutnya yaitu penggaraman ikan. Penggaraman ikan bertujuan agar ikan menjadi asin selama proses pembuatan. Selain itu, garam yang digunakan dalam pembuatan ikan asin adalah garam halus, agar menghasilkan ikan asin berwarna putih dan bertekstur lunak. Jika diredam dalam air, ikan asin akan cepat menyerap air sehingga bila digoreng akan berasa seperti ikan segar (Astawan, 2004). Selanjutnya ikan dibiarkan selama 1 jam dalam baskom dengan kondisi tertutup (Gambar 3). Selanjutnya ikan dicuci kembali untuk mengurangi garam 
yang menempel di daging ikan. Pencucian bisa dilakukan beberapa kali untuk mendapatkan hasil ikan yang baik (Susianawati, 2006)

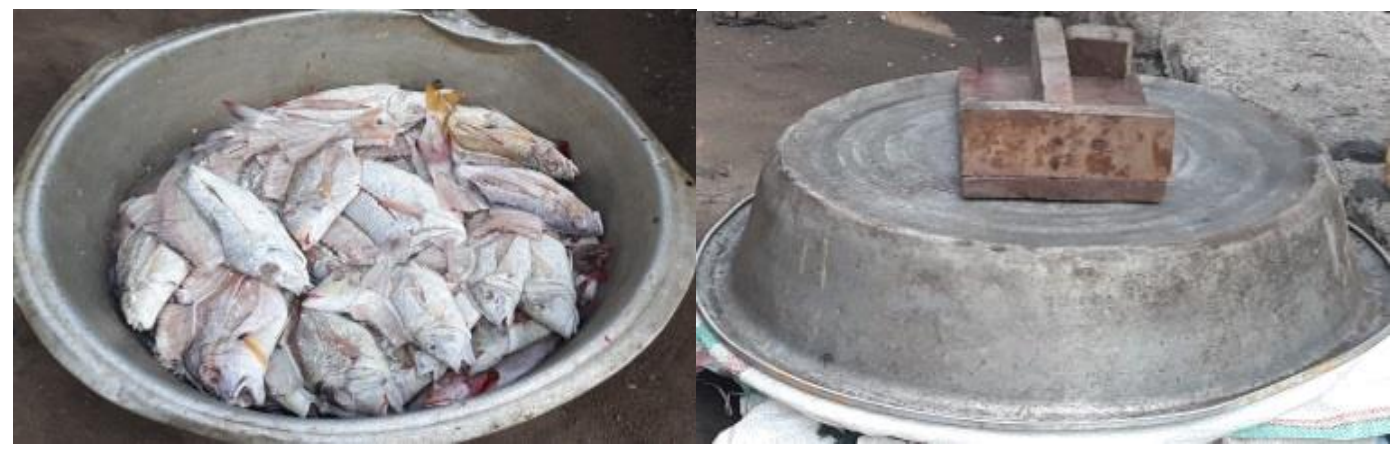

Gambar 3. Kondisi selesai penggaraman bahan baku.

Setelah pencucian, ikan dijemur di atas para-para (Gambar 4), pengeringan di bawah terik sinar matahari selam $1-3$ hari. Ikan dibolakbalik sehingga ikan akan kering secara merata. Keuntungannya dari pengeringan dengan sinar matahari adalah biaya relatif lebih murah, pelaksanaan mudah, sedangkan kelemahannya adalah waktu pengeringan sukar untuk ditentukan serta kebersihannya sukar dikontrol (Winarno et al.,1980).

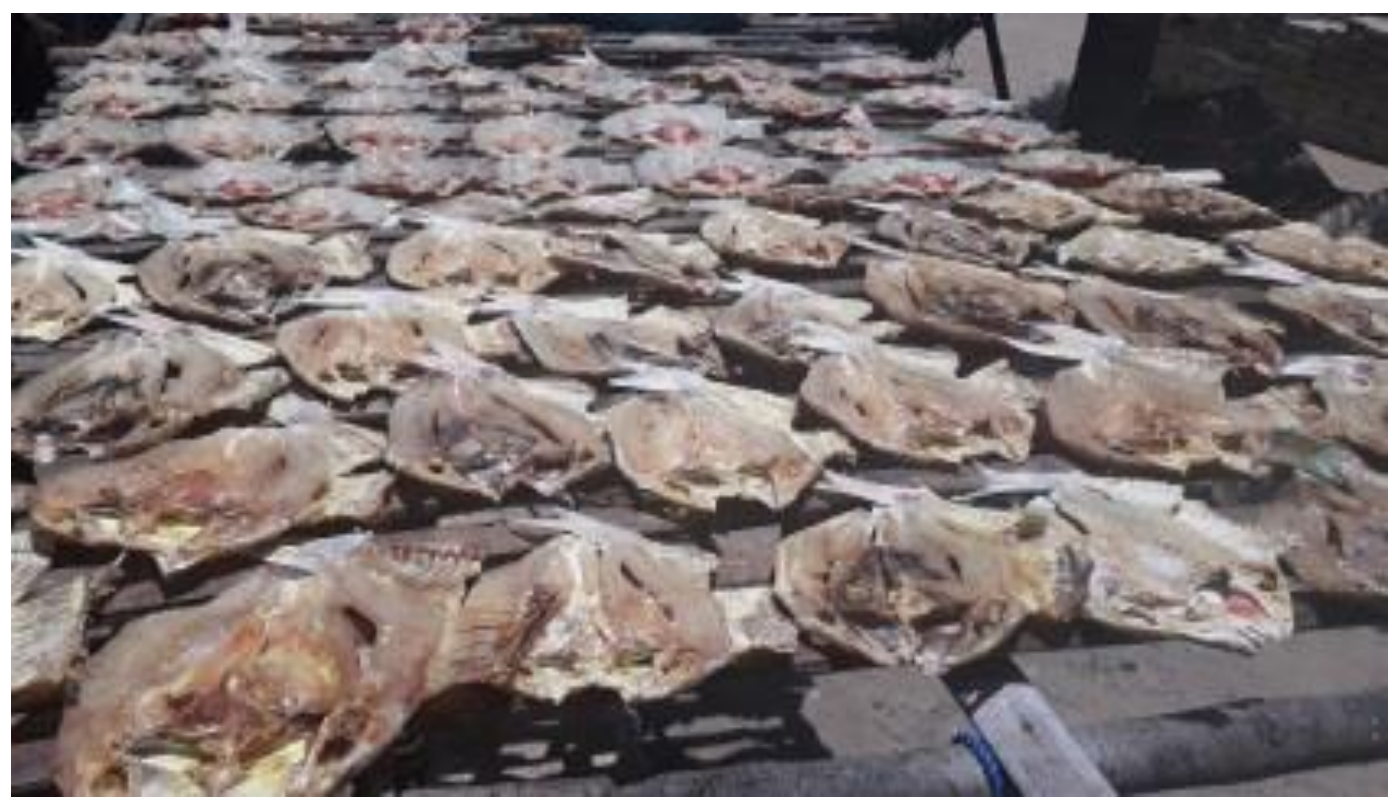

Gambar 4. Pengeringan ikan di atas para-para.

\section{Uji Organoleptik}

Organoleptik merupakan cara uji dengan menggunakan indra manusia sebagai alat utama untuk mengukur daya penerimaan terhadap makanan. Pengujian sensori atau pengujian dengan indra atau dikenal juga dengan pengujian organoleptik sudah ada sejak manusia mulai 
menggunakan indranya untuk menilai kualitas dan keamanan suatu makanan dan minuman (Setyaningsih et al., 2010). Uji organoleptik yang dilakukan dalam penelitian ini meliputi uji kenampakan, rasa, bau, tekstur, dan jamur. Hasil uji organoleptik ikan asin di Desa Galo-Galo disajikan dalam Gambar 5 berikut.

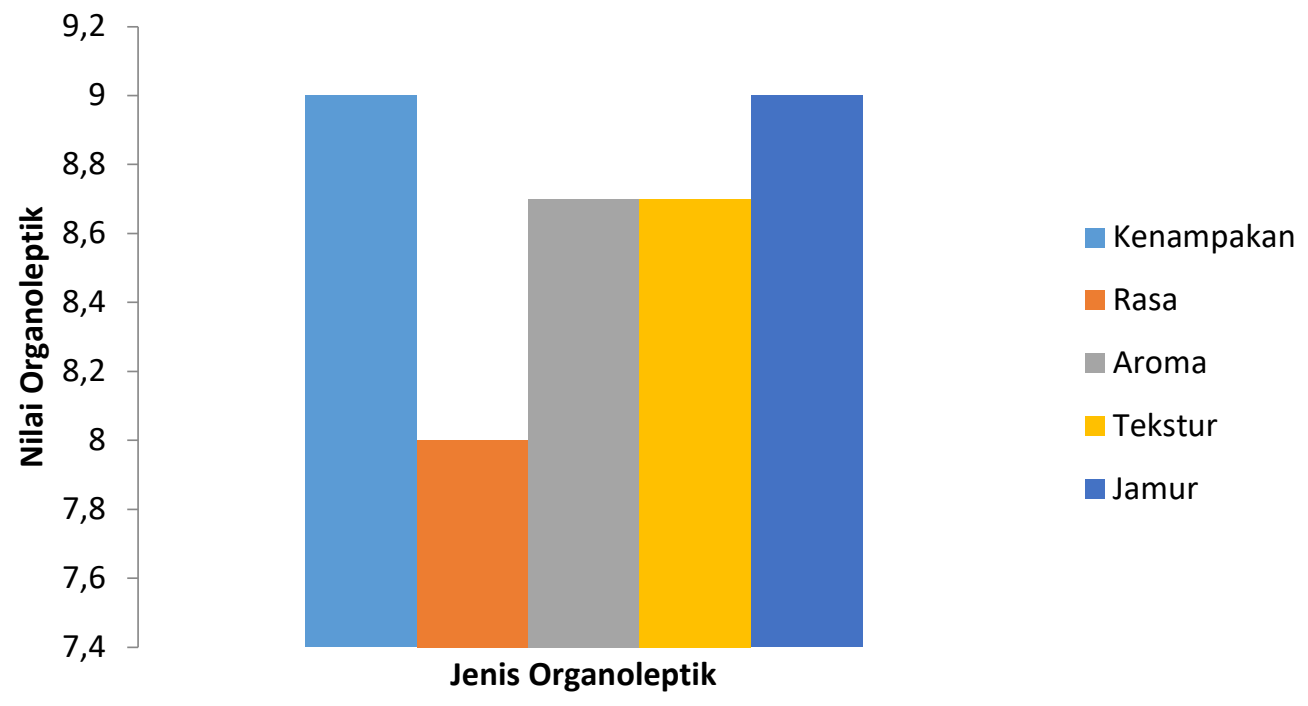

Gambar 5. Hasil uji organoleptik ikan asin di Desa Galo-Galo.

Berdasarkan Gambar 5 di atas dapat dilihat bahwa nilai organoleptik secara keseluruhan memenuhi syarat mutu dan keamanan pangan, karena nilai organoleptik yang diperoleh minimal 8. Sebagaimana yang ditetapkan dalam SNI, syarat mutu dan keamanan pangan ikan asin untuk nilai organoleptik minimal 7.

\section{Kenampakan}

Kenampakan merupakan karasteristik pertama yang dilihat, dinilai, disukai oleh konsumen dalam memilih atau mengonsumsi suatu produk (Winarno, 1995). Hasil uji organoleptik kenampakan ikan asin, menunjukan ikan asin yang diproduksi memenuhi syarat. Hal ini dapat dilihat dengan rata-rata panelis memberikan nilai 9. Reo (2013) melaporkan bahwa produksi ikan kakap merah asin yang dihasilkan memiliki nilai organoleptik kenampakan dengan skor tertinggi 8,6.

\section{Rasa}

Hasil uji organoleptik rasa ikan asin menunjukan bahwa panelis memberikan nilai rata-rata 8 . Sedangkan nilai rasa terendah yang diberikan panelis adalah 7 dan nilai tertinggi yang diberikan panelis adalah 9. Reo (2013) melaporkan bahwa tingkat kesukaan cita rasa ikan kakap merah asin diperoleh skor terendah adalah 5,8 dan tingkat kesukaan cita rasa yang tertinggi adalah 8,2. Menurut Peranginangin (1983), garam 
dapat merangsang cita rasa dan menambahkan rasa enak. Selanjutnya Astawan (1997) menjelaskan bahwa daya tarik ikan asin salah satunya terletak pada rasa yang khas.

\section{Bau}

Menurut Astawan (1997) daya tarik ikan asin terletak pada aromanya yang khas, selain rasa dan tekstur. Reo (2013) melaporkan bahwa tingkat kesukaan bau ikan kakap merah asin terendah adalah 5,6 (bau tambahan mengganggu, tidak busuk, agak tengik), sedangkan skor rata-rata tingkat kesukaan bau yang tertinggi adalah 8,33 (kurang harum, tanpa bau tambahan). Hasil uji organoleptik bau ikan asin dari Desa GaloGalo panelis memberikan nilai rata-rata 8,7 (harum spesifik tanpa bau tambahan).

\section{Tekstur}

Tekstur merupakan segala hal yang berhubungan dengan mekanik, rasa, sentuhan, penglihatan yang meliputi penilaian terhadap kebasahan, kering, keras, halus, kasar dan berminyak (Soekarto dan Hubeis, 2000). Faktor tekstur diantaranya adalah rabaan oleh tangan, keempukan dan mudah dikunyah (Meilgaard et al., 1999 dalam Garwan, 2009).

Hasil penelitian untuk tingkat penerimaan panelis terhadap nilai tekstur ikan asin yang berasal dari desa galo-galo tergambar pada diagram yakni berkisar pada 8,6 yang artinya tekstur ikan asin pada Desa Galo-Galo bertekstur padat, kompak, lentur dan kurang kering. Dari hasil yang telah diketahui maka nilai ikan garam masih sesaui dengan standar Nasional Indonesia SNI 2009. Syarat Mutu Ikan Asin Kering SNI 27211:2009) yang menyatakan tekstur masih dapat diterima.

\section{Jamur}

Kerusakan pada ikan asin dapat di sebabkan karena ikan terkena jamur. Parameter jamur pada ikan asin di Desa Galo-Galo mendapatkan nilai 9 pada semua sampel. Hal ini dikarenakan tidak ditemukannya jamur pada semua ikan garam. Lavlinesia (1995) melaporkan bahwa ketiadaan jamur dikarenakan bahan baku masih segar dan produk baru saja jadi dan tidak ada waktu penyimpanan.

\section{KESIMPULAN}

Proses pembuatan ikan asin dimulai dari ikan dibersihkan dari sisik, dibuang isi perut dan insang, dicuci, dibilas, diberi garam, direndam, dicuci kembali, dan dijemur. Hasil uji organoleptik ikan asin oleh panelis konsumen menunjukkan bahwa ikan asin dari Desa Galo-Galo layak dikonsumsi karena nilai organoleptik $>7$. 


\section{DAFTAR PUSTAKA}

Astawan M. 1997. Mengenal Makanan Tradisional Produk Olahan Ikan. ISJD. pdii.lipi.go.id/admin/jurnal/83975862.pdf.

Astawan M. 2004. Ikan yang Sedap dan Bergizi. Tiga Serangkai. Solo.

Badan Standardisasi Nasional. 2009. Syarat Mutu Ikan Asin Kering SNI 27211:2009.

Badan Standar Nasional. 2009. Standar Nasional Indonesia (SNI) Ikan Asin Kering. Kumpulan Standar Metode Pengujian Mutu Hasil Perikanan. Jakarta.

Garwan R. 2009. Perkembangan Histamin selama Proses Fermentasi dan Penyimpanan Produk Bakasang Ikan Cakalang (Katsuwonus pelamis Lin.). [Tesis]. Institut Pertanian Bogor. Bogor.

Lavlinesia. 1995. Kajian Beberapa Faktor Pengembangan Volumetrik dan Kerenyahan Kerupuk Ikan [Tesis]. Program Pascasarjana, Institut Pertanian Bogor. Bogor.

Margono T., Suryati D. dan Hertina S. 2000. Ikan Asin Cara Kombinasi Penggaraman dan Peragian (ikan peda). www.warintek.ristek.go.id/pangankesehatan/pangan/piwp/ikanasink ombinasi.

Peranginangin R. 1983. Penelitian Dendeng Tawes (Puntius javanicus) Dalam Berbagai Bentuk Olahan. Laporan Penelitian Teknologi Perikanan. Balai Pengembangan Pertanian. Departemen Pertanian. Jakarta.

Reo A.R. 2013. Mutu Ikan Kakap Merah yang Diolah dengan Perbedaan Konsentrasi Larutan Garam dan Lama Pengeringan. Jurnal Perikanan dan Kelautan Tropis. 9 (1): 35-44.

Setyaningsih D., Anton A. dan Maya P.S. 2010. Analisis Sensori untuk Industri Pangan. IPB Press. Bogor

Soekarto ST, Hubeis M. 2000. Metodologi Penilaian Organoleptik. Petunjuk Laboratorium. Bogor: Pusat Antar Universitas Pangan dan Gizi, Program Studi Ilmu Pangan, Institut Pertanian Bogor.

Susianawati R. 2006. Kajian Penerapan GPM dan SSOP pada Produk Ikan Asin Kering dalam upaya peningkatan Keamanan Pangan di Kabupaten Kendal. Tesis: Program Studi Magister Manajemen Surabaya Pantai. Universitas Diponegoro. Semarang. 
E-ISSN: 2527-5186. P-ISSN: 2615-5958

Jurnal Enggano Vol. 5, No. 2, September 2020: 122-131

Wibowo. 1995. Industri Pengasapan Ikan. Penerbit Swadaya. Jakarta.

Winarno F.G., S. Fardiaz dan D. Fardiaz. 1980. Pengantar Teknologi Pangan. PT. Gramedia. Jakarta.

Winarno F.G. 1995. Kerusakan Bahan Pangan dan Cara Pengolahannya. Departemen Teknologi Pertanian. Institut Pertanian Bogor. Bogor. 